University of Nebraska - Lincoln

DigitalCommons@University of Nebraska - Lincoln

USDA National Wildlife Research Center - Staff Publications
U.S. Department of Agriculture: Animal and Plant Health Inspection Service

2012

\title{
Characterization of Newcastle Disease Viruses Isolated from Cormorant and Gull Species in the United States in 2010
}

Diego G. Diel

Department of Agriculture (USDA), diego.diel@ars.usda.gov

Patti J. Miller

Department of Agriculture (USDA), Patti.Miller@ars.usda.gov

Paul C. Wolf

USDA, paul.c.wolf@aphis.usda.gov

Randall M. Mickley

USDA, APHIS, Wildlife Services

Anthony R. Musante

USDA, APHIS, Wildlife Services

See next page for additional authors

Follow this and additional works at: https://digitalcommons.unl.edu/icwdm_usdanwrc

Diel, Diego G.; Miller, Patti J.; Wolf, Paul C.; Mickley, Randall M.; Musante, Anthony R.; Emanueli, Daniel C.; Shively, Kirk J.; Pedersen, Kerri; and Afonso, Claudio L., "Characterization of Newcastle Disease Viruses Isolated from Cormorant and Gull Species in the United States in 2010" (2012). USDA National Wildlife Research Center - Staff Publications. 1122.

https://digitalcommons.unl.edu/icwdm_usdanwrc/1122

This Article is brought to you for free and open access by the U.S. Department of Agriculture: Animal and Plant Health Inspection Service at DigitalCommons@University of Nebraska - Lincoln. It has been accepted for inclusion in USDA National Wildlife Research Center - Staff Publications by an authorized administrator of DigitalCommons@University of Nebraska - Lincoln. 


\section{Authors}

Diego G. Diel, Patti J. Miller, Paul C. Wolf, Randall M. Mickley, Anthony R. Musante, Daniel C. Emanueli, Kirk J. Shively, Kerri Pedersen, and Claudio L. Afonso 


\title{
Characterization of Newcastle Disease Viruses Isolated from Cormorant and Gull Species in the United States in 2010
}

\author{
Diego G. Diel, ${ }^{\mathrm{A}}$ Patti J. Miller, ${ }^{\mathrm{A}}$ Paul C. Wolf, ${ }^{\mathrm{B}}$ Randall M. Mickley, ${ }^{\mathrm{C}}$ Anthony R. Musante, ${ }^{\mathrm{D}}$ Daniel C. Emanueli, ${ }^{\mathrm{E}}$ \\ Kirk J. Shively, ${ }^{\mathrm{F}}$ Kerri Pedersen, ${ }^{\mathrm{G}}$ and Claudio L. Afonso ${ }^{\mathrm{AH}}$ \\ ${ }^{A}$ United States, Department of Agriculture (USDA), Agricultural Research Service, Southeast Poultry Research Laboratory, \\ 934 College Station Road, Athens, GA 30605 \\ ${ }^{B}$ USDA, Animal and Plant Health Inspection Service (APHIS), Wildlife Services, 644 Bayfield Street, Suite 215, St. Paul, MN 55107 \\ ${ }^{\mathrm{C}}$ USDA, APHIS, Wildlife Services 9 Main Street, Suite 1M, Sutton, MA 01590 \\ ${ }^{D}$ USDA, APHIS, Wildlife Services, 59 Chenell Drive, Suite 7, Concord, NH 03301 \\ ${ }^{E}$ USDA, APHIS, Wildlife Services, 1568 Whitehall Road, Annapolis, MD 21409 \\ FUSDA, APHIS, Wildlife Services, 79 Leighton Road, Suite 12, Augusta, ME 04330 \\ GUSDA, APHIS, Wildlife Services, 4101 LaPorte Avenue, Fort Collins, CO 80521
}

Received 23 August 2011; Accepted and published ahead of print 6 October 2011

\begin{abstract}
SUMMARY. Newcastle disease virus (NDV), a member of the genus Avulavirus of the family Paramyxoviridae, is the causative agent of Newcastle disease (ND), a highly contagious disease that affects many species of birds and which frequently causes significant economic losses to the poultry industry worldwide. Virulent NDV (vNDV) is exotic in poultry in the United States; however, the virus has been frequently associated with outbreaks of ND in cormorants, which poses a significant threat to poultry species. Here, we present the characterization of $13 \mathrm{NDV}$ isolates obtained from outbreaks of ND affecting cormorants and gulls in the states of Minnesota, Massachusetts, Maine, New Hampshire, and Maryland in 2010. All 2010 isolates are closely related to the viruses that caused the ND outbreaks in Minnesota in 2008, following the new evolutionary trend observed in cormorant NDV isolates since 2005. Similar to the results obtained with the 2008 isolates, the standard United States Department of Agriculture F-gene real-time reverse-transcription PCR (RRT-PCR) assay failed to detect the 2010 cormorant viruses, whereas all viruses were detected by a cormorant-specific F-gene RRTPCR assay. Notably, NDV-positive gulls were captured on the eastern shore of Maryland, which represents a significant geographic expansion of the virus since its emergence in North America. This is the first report of vNDV originating from cormorants isolated from wild birds in Maryland and, notably, the first time that genotype V vNDV has been isolated from multiple wild bird species in the United States. These findings highlight the need for constant epidemiologic surveillance for NDV in wild bird populations and for consistent biosecurity measures to prevent the introduction of the agent into domestic poultry flocks.
\end{abstract}

RESUMEN. Caracterización de los virus de la Enfermedad de Newcastle aislados de Cormoranes y de gaviotas en los Estados Unidos en el 2010.

La enfermedad de Newcastle virus (NDV), un miembro del género Avulavirus de la familia Paramyxoviridae, es el agente causal de la enfermedad de Newcastle (ND), una enfermedad altamente contagiosa que afecta a muchas especies aviares y que con frecuencia causa importantes pérdidas económicas para la industria avícola en todo el mundo. La enfermedad de Newcastle virulenta (vNDV) es exótica para las aves comerciales en los Estados Unidos, sin embargo, el virus ha sido asociado con frecuencia a los brotes de enfermedad de Newcastle en cormoranes, lo que representa una amenaza significativa para las aves comerciales. En este trabajo se presenta la caracterización de 13 cepas del virus de Newcastle obtenidas de los brotes de la enfermedad de Newcastle que afectaron a los cormoranes y gaviotas en los estados de Minnesota, Massachusetts, Maine, New Hampshire, y Maryland en el año 2010. Todos los aislamientos del 2010 están estrechamente relacionados con el virus que causó los brotes de Newcastle en Minnesota en el año 2008, siguiendo la nueva tendencia de evolución observada en los aislamientos de Newcastle de cormoranes desde el 2005. De manera similar con los resultados obtenidos de los aislamientos del 2008, la técnica estándar de transcripción reversa y reacción en cadena de la polimerasa en tiempo real (RRT-PCR) para el gene de la proteína F, desarrollada por el Departamento de Agricultura de los Estados Unidos, no pudo detectar los virus de cormoranes del año 2010, mientras que todos los virus fueron detectados por un ensayo RRT-PCR para la proteína F específica de los virus de cormoranes. De manera sobresaliente, gaviotas positivas al virus de Newcastle fueron capturadas en la costa oriental de Maryland, lo que representa una expansión geográfica significativa del virus desde su aparición en América del Norte. Este es el primer reporte del aislamiento del virus de Newcastle de aves silvestres en Maryland y, sobre todo, es la primera vez que el genotipo V del virus de Newcastle ha sido aislado de varias especies de aves silvestres en los Estados Unidos. Estos resultados destacan la necesidad de una constante vigilancia epidemiológica para la enfermedad de Newcastle en las aves silvestres y de las medidas de bioseguridad constantes para prevenir la introducción del agente en las parvadas de aves comerciales.

Key words: Newcastle disease virus, NDV, Newcastle disease, cormorants, gulls, outbreak

Abbreviations: $\mathrm{bp}=$ base pairs; $\mathrm{F}=$ fusion protein; $\mathrm{HI}=$ hemagglutination-inhibition; $\mathrm{ICPI}=$ intracerebral pathogenicity index; $\mathrm{L}=$ large polymerase; $\mathrm{M}=$ matrix protein; $\mathrm{ND}=$ Newcastle disease; $\mathrm{NDV}=$ Newcastle disease virus; $\mathrm{NP}=$ nucleoprotein; OIE $=$ World Organization for Animal Health; P = phosphoprotein; RRT-PCR = real-time reverse-transcription PCR; SEPRL $=$ Southeast Poultry Research Laboratory; SPF $=$ specific pathogen free; USDA = United States Department of Agriculture; $\mathrm{V}=\mathrm{V}$ protein; $\mathrm{vNDV}=$ virulent Newcastle disease virus

Newcastle disease (ND) is a highly contagious disease that affects many species of birds and which frequently causes significant economic

${ }^{\mathrm{H}}$ Corresponding author. E-mail: claudio.afonso@ars.usda.gov losses to the poultry industry worldwide (3). The causative agent of ND is Newcastle disease virus (NDV) or avian paramyxovirus type 1, a member of the genus Avulavirus of the family Paramyxoviridae (14). The NDV genome consists of a single-stranded, negative-sense RNA molecule of approximately $15.2 \mathrm{~kb}$ that contains six genes encoding 
seven proteins (nucleoprotein $[\mathrm{N}]$; phosphoprotein $[\mathrm{P}]$; V protein $[\mathrm{V}]$; matrix protein $[\mathrm{M}]$; fusion protein $[\mathrm{F}]$; and large polymerase $[\mathrm{L}]$ ) $(14,20)$.

Newcastle disease is characterized by a wide range of clinical signs depending on the virulence of the virus strain and species of bird affected (15). Historically, NDV strains have been classified as velogenic (highly virulent), mesogenic (moderately virulent), and lentogenic (mildly virulent), based on the pathogenicity in chickens and chicken embryos $(2,20)$. Velogenic strains are further divided into neurotropic and viscerotropic, with neurotropic strains causing respiratory and neurologic signs and viscerotropic strains causing hemorrhagic intestinal lesions (2,20). Virulent NDV (vNDV) outbreaks must be reported to the World Organisation for Animal Health (OIE). The OIE defines ND as an infection caused by an avian paramyxovirus type 1 that has an intracerebral pathogenicity index (ICPI) in 1-day-old chickens of 0.7 or greater, has multiple basic amino acid residues (at least three residues) at the $\mathrm{C}$-terminus of the fusion (F) protein cleavage site (residues 113-116) and a phenylalanine residue at position 117 (17). All velogenic and some mesogenic strains of NDV are considered virulent for chickens.

NDV is known for its ability to infect many species of birds with more than 250 species in 27 orders being susceptible (3). NDV infections in wild birds represent a constant threat to the poultry industry and pose significant difficulties to disease control strategies (3). Although infections of wild birds are usually subclinical with most NDV isolates being lentogenic, outbreaks of velogenic NDV have been frequently reported in cormorants in several regions of the world including Canada and northern states of the United States $(7,9,13,18)$. In this species, the disease is characterized mainly by neurologic signs including head tremors, ataxia, and paralysis of the legs and wings, circling, and in some cases blindness $(12,13)$. High mortality rates (up to $92 \%$ ) are observed in juvenile birds with adult birds being more resistant to the disease, although paresis and other neurologic signs have been reported $(7,11)$.

NDV has been associated with cormorants and gulls since 1949, when hemagglutination-inhibition (HI) antibodies were detected in birds captured in Scotland (5). In North America, the first outbreak of NDV in cormorants and gulls was reported in 1975 in Canada (8) and then in 1990 in the provinces of Alberta, Saskatchewan, and Manitoba (26). In 1992, the disease was observed for the first time in cormorants in the United States, resulting in the death of approximately 20,000 double-crested cormorants (Phalacrocorax auritus) in seven northern states and in one province of Canada (7). Since then, vNDV has been repeatedly reported in cormorants in United States and Canada $(7,9,12,13,18)$, indicating that it became established in this species $(3,7)$. Notably, in the United States, pigeons and cormorants represent the only known natural reservoirs of vNDV in wild bird populations $(3,16)$; therefore, it is important to continually evaluate the evolution and pathogenicity of NDV isolates obtained from these species.

Here, we present the characterization of $13 \mathrm{NDV}$ isolates obtained from outbreaks of ND that occurred in 2010 in the states of Minnesota, Massachusetts, Maine, New Hampshire, and Maryland. NDV isolates were obtained from double-crested cormorants, great cormorants (Phalacrocorax carbo), herring gulls (Larus argentatus), and great black-backed gulls (Larus marinus). Detection of NDV in herring and great black-backed gulls in Maryland represents a significant geographic and host range expansion for the virus in wildlife (22). This is the first report of vNDV originating from cormorants isolated from wild birds in Maryland and, notably, the first time that genotype $\mathrm{V}$ vNDV has been isolated from multiple wild bird species in the United States. These observations highlight the need for constant epidemiologic surveillance for NDV in wild bird populations and for consistent biosecurity measures to prevent the introduction of the agent into domestic poultry flocks.

\section{MATERIALS AND METHODS}

Viruses and virus isolation. Thirteen NDV isolates were obtained from the United States Department of Agriculture (USDA) Southeast Poultry Research Laboratory (SEPRL) repository. The viruses were isolated from oral and/or cloacal swabs samples collected during outbreaks of ND affecting cormorants (double-crested and great cormorants) and gulls (herring and black-backed gulls) in the states of Minnesota, Massachusetts, Maine, New Hampshire, and Maryland in 2010. Viruses were isolated from swab samples by standard virus isolation in specific-pathogen-free (SPF) embryonated chicken eggs (2).

ICPI test. The pathogenicity of nine cormorant-gull NDV isolates was assessed by using the ICPI test (2). One-day-old SPF chickens were inoculated intracerebrally with $0.1 \mathrm{ml}$ of a $1: 10$ dilution of infective allantoic fluid. Chicks were monitored during an 8-day observation period and scored as normal (score $=0$ ), sick or paralyzed (score $=1$ ), and dead $($ score $=2)$. Total scores were determined and the mean daily scores were calculated to obtain the ICPI (2).

RNA extraction and real-time RT-PCR (RRT-PCR). All NDV isolates $(n=13)$ were propagated in SPF embryonated chicken eggs. Total RNA was extracted from allantoic fluid using TRIzol ${ }^{\circledR}$ LS (Invitrogen, Carlsbad, CA) following the manufacturer's protocol. All isolates were tested using the USDA standard F-gene RRT-PCR assay (25) and a cormorant-specific F-gene RRT-PCR assay (18).

Sequencing of the fusion gene. The complete F-gene coding sequences or a 374-base pair (bp) region of the F-gene (1) were amplified from the genome of all NDV isolates by using the Superscript ${ }^{\mathrm{TM}}$ III Onestep RT-PCR kit (Invitrogen) and F-gene-specific primers $(1,25)$. PCR reactions were subjected to electrophoresis in $1 \%$ agarose gels and the DNA bands were excised from the gel and purified by using the QIAquick Gel Extraction Kit (Qiagen, Valencia, CA).

All sequencing reactions were performed with fluorescent dideoxynucleotide terminators in the ABI 3700 automated sequencer (Applied Biosystems Inc., Foster City, CA). Sequence editing and assembly was performed with LaserGene sequence analysis software package (LaserGene, version 5.07; DNAStar, Inc., Madison, WI).

Phylogenetic analysis. A 373-bp region of the F-gene (1) was used to construct the phylogenetic trees and to localize the 2010 cormorant-gull NDV isolates $(n=13)$ among other class II genotype reference sequences $(n=67)$. Phylogenetic analysis was performed by using MEGA4 software (MEGA, version 4) (23). The evolutionary distances were inferred by using the neighbor-joining method (19) with 100 bootstrap replicates and included the first, second, and third coding and noncoding positions.

Accession numbers. The sequences of the F-gene of the NDV isolates characterized in the present study are available on GenBank under the accession numbers JN255784, JN255773, JN255774, JN255775, JN255776, JN255777, JN255778, JN255779, JN255780, JN255781, JN255782, JN255783, JN255784, JN255785.

\section{RESULTS}

During the 2010 cormorant-gull NDV outbreaks in Minnesota, Massachusetts, Maine, New Hampshire, and Maryland, the USDA SEPRL received 62 samples (oral and/or cloacal swabs) collected from various avian species including double-crested cormorants (Phalacrocorax auritus; $n=31$ ), great cormorants (Phalacrocorax carbo; $n=2$ ), great black-backed gulls (Larus marinus; $n=15$ ), herring gulls (Larus argentatus; $n=2$ ), and mallards (Anas platyrhynchos; $n=1$ ). NDV was isolated or detected by RRT-PCR in $32(62.7 \%)$ of these samples, including samples from double-crested and great cormorants and from great black-backed and herring gulls. Thirteen of these isolates were characterized in the present study. All isolates were subjected to 
Table 1. Virulent Newcastle disease viruses isolated from cormorants and gulls in the United States in 2010.

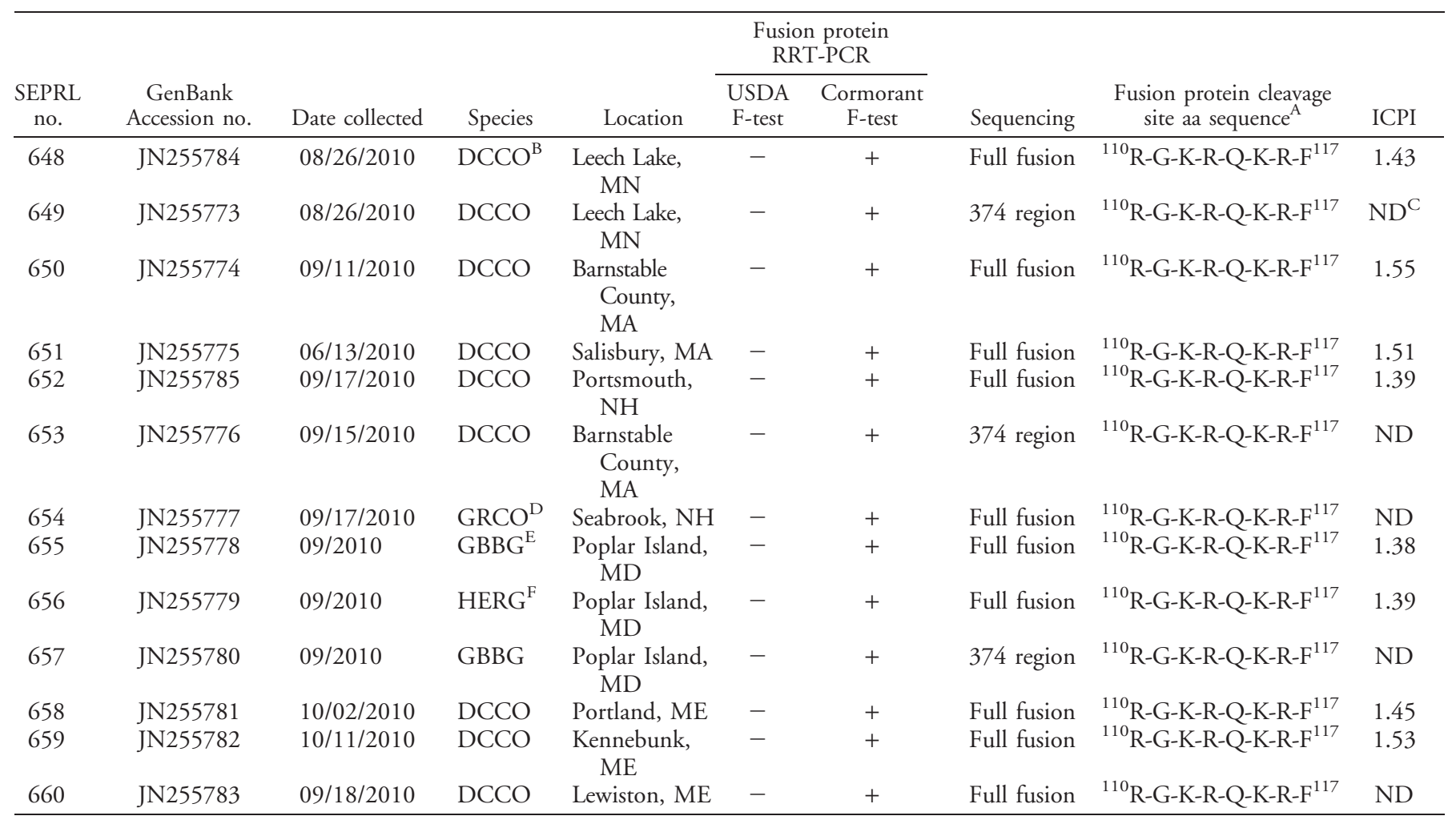

${ }^{\mathrm{A}}$ Fusion protein cleavage site amino acid residues 110 to 117 .

${ }^{\mathrm{B}} \mathrm{DCCO}=$ double-crested cormorant (Phalacrocorax auritus).

${ }^{\mathrm{C}} \mathrm{ND}=$ not determined.

${ }^{\mathrm{D}} \mathrm{GRCO}=$ great cormorant $($ Phalacrocorax carbo).

${ }_{\mathrm{E}}^{\mathrm{GBBG}}=$ great black-backed gull (Larus argentatus).

${ }^{\mathrm{F}} \mathrm{HERG}=$ herring gull (Larus marinus).

phylogenetic analysis to determine the evolutionary distances to other NDV strains and eight isolates were further characterized for their pathogenicity in 1-day-old chickens by standard ICPI tests.

Clinical signs observed in birds affected by ND during the 2010 outbreaks included torticollis, paralysis of the legs and wings, tremors, and lack of muscular coordination. Approximately 1100 birds died during these outbreaks and among the affected species were doublecrested cormorants, great cormorants, black-backed gulls, and herring gulls. Other avian species such as ring-billed gulls, mallards, egrets, terns, and American white pelicans were found dead (22); however, no evidence of NDV infection was detected in these species (data not shown). A summary with the information about the NDV isolates characterized here is presented in Table 1.

To assess the pathogenicity of the 2010 cormorant NDV isolates, eight viruses were subjected to the ICPI test in 1-day-old chickens. All viruses presented ICPI values between 1.38 and 1.55 (Table 1), which is typical for viruses isolated from cormorants (18), and characterize them as vNDV based on the OIE standards. Additionally, all viruses presented a virulent fusion protein cleavage site with three basic amino acids at the C-terminus of the protein (positions 113-116) and a phenylalanine residue at position 117 (Table 1) (17).
All isolates were tested by the USDA-validated RRT-PCR F-gene assay (25) and by the cormorant RRT-PCR assay (18). Similar to the results obtained with the 2008 cormorant isolates (18), the USDA-validated Fgene assay failed to detect all 2010 isolates, whereas all isolates were detected by the cormorant F-gene RRT-PCR assay (Table 1).

The evolutionary distances between the 2010 cormorant isolates and other NDV strains were assessed by phylogenetic analysis. A 373-bp region of the F-gene (1) was used for the phylogenetic analysis of 13 isolates from 2010 and other reference strains $(n=67)$. All 2010 cormorant isolates clustered with the 2008 cormorant isolates within the class II genotype $\mathrm{V}$ group (Fig. 1). The nearest ancestors of the 2010 viruses are the viruses G/2008/US/MN/284019481, G/2008/ US/MN/284019485, and G/2008/US/MN/284019495 obtained in the 2008 cormorant ND outbreak in Minnesota. Both 2008 and 2010 viruses are closely related to a virus isolate obtained during an outbreak in Nevada in 2005 (cormorant/2005/US/NV/19529-04), suggesting a common ancestor for these viruses (Fig. 1). Phylogenetic analysis of the complete coding sequences of the F-gene revealed a similar distribution of the viruses in the phylogenetic tree, with the 2010 isolates clustering with the 2008 viruses within the class II genotype V group (data not shown).

Fig. 1. Phylogenetic analysis of the 2010 cormorant NDV isolates and other reference strains on GenBank. A 373-bp region of the F-gene was used to construct the phylogenetic tree and to localize the 2010 isolates among other NDV strains. The evolutionary history was inferred using the neighbor-joining method (19). The optimal tree with the sum of branch length $=2.27030740$ is shown. The percentage of replicate trees in which the associated taxa 


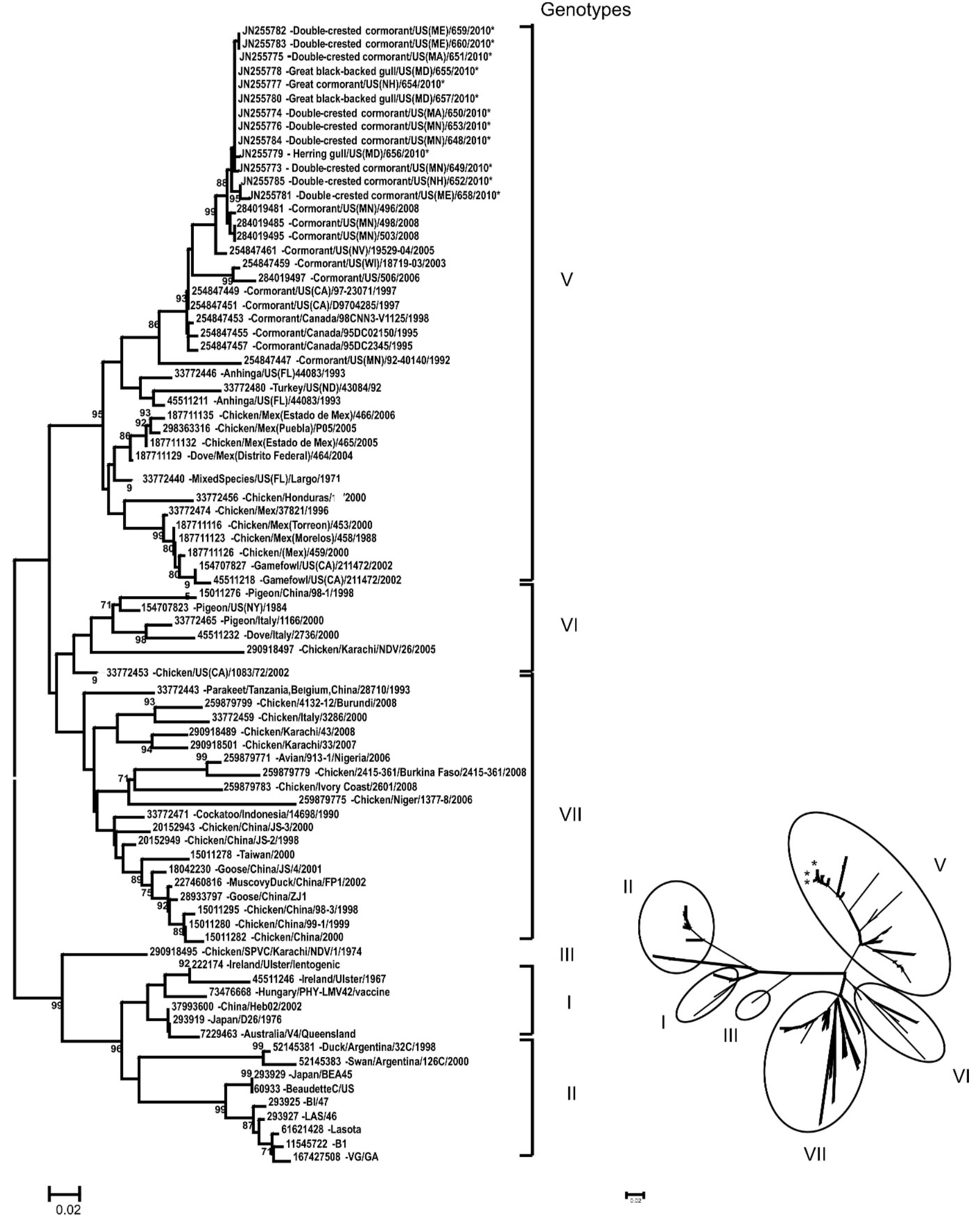

clustered together in the bootstrap test (100 replicates) is shown next to the branches (6). The tree is drawn to scale, with branch lengths in the same units as those of the evolutionary distances used to infer the phylogenetic tree. The evolutionary distances were computed using the maximum composite likelihood method (24) and are in the units of the number of base substitutions per site. Codon positions included were 1 st $+2 \mathrm{nd}+3 \mathrm{rd}+\mathrm{Noncoding}$. All positions containing gaps and missing data were eliminated from the dataset (complete deletion option). There were a total of 14,903 positions in the final dataset. Phylogenetic analysis was conducted in MEGA4 (23). ${ }^{*}=$ NDV isolates obtained during the 2010 outbreak. 


\section{DISCUSSION}

In this study we present the characterization of $13 \mathrm{NDV}$ isolates obtained during outbreaks of ND that affected cormorants and gulls in the states of Minnesota, Massachusetts, Maine, New Hampshire, and Maryland in 2010. Notably, NDV-positive gulls were captured on the eastern shore of Maryland, $60 \mathrm{mi}$ away from commercial poultry houses that are part of the Delmarva Poultry Industry. This represents the first report of NDV isolation from wild birds in Maryland, indicating a significant eastward expansion of the virus since its emergence in North America (22).

NDV emerged in cormorants in North America in 1990 (26), and the first occurrence of the disease in cormorants in the United States was in 1992 (7). Since then, vNDV has been frequently associated with outbreaks of ND in cormorants, leading to variable mortality rates $(<1$ to $92 \%)$ in juvenile birds $(7,9,12,13,18)$. The periodic occurrence of ND in cormorants indicates that vNDV became established in this species (7). Indeed, pigeons and cormorants are the only known natural reservoirs of vNDV in the wild in the United States $(3,16)$, highlighting the importance of constant epidemiologic surveillance and proactive characterization of NDV isolates circulating in these species.

The pathogenicity of cormorant NDV isolates has not changed since its emergence in this species in 1949 (5), with all characterized isolates being classified as mesogenic or velogenic neurotropic viruses $(7,9,12,13,18)$. The isolates characterized here presented ICPI values ranging from 1.38 to 1.55 , which is consistent with vNDV strains $(3,17)$. The clinical signs (torticollis, paralysis of the legs and wings, tremors, and lack of muscular coordination) observed in affected birds during the 2010 outbreaks (22) are consistent with the involvement of the central nervous system and further suggest that these viruses belong to the neurotropic NDV pathotype. However, the possibility that some of these isolates belong to the viscerotropic pathotype cannot be formally excluded.

Virulent NDV is exotic in poultry in the United States (3), but the frequent association of the virus with outbreaks in cormorants poses a significant threat to the poultry industry. Here, vNDV was isolated from wild birds (gulls) collected in close proximity ( $\sim 60$ miles) to the Delmarva poultry industry in Maryland, which is of great concern given the high concentration of poultry in this area. Isolation of vNDV from gulls represents an additional risk to poultry flocks, given that these birds are often found in poultry farms (10) and, therefore, could potentially introduce the virus into poultry flocks. Although of rare occurrence, there is strong evidence indicating that vNDV has been transmitted from cormorants to a turkey flock in North Dakota in $1992(9,21)$, which highlights the importance of consistent biosecurity measures to prevent the introduction of vNDV, circulating in wild bird populations, into commercial poultry flocks.

Phylogenetic analysis revealed that the 2010 cormorant NDV isolates are closely related to the NDV strains that caused the outbreak in Minnesota in 2008 (18) with all 2010 isolates clustering with the 2008 viruses in the class II genotype V group (Fig. 1). Notably, since the emergence of ND in cormorants in North America, all viruses have been classified in the same genetic lineage of genotype $\mathrm{V}$, suggesting coevolution of the virus with this particular host species. Analysis of the nucleotide sequences of the F-gene cleavage site revealed that the evolutionary changes observed in the 2008 viruses, which led to failure of the USDA F-gene RRT-PCR assay in detecting the cormorant viruses (18), are also present in the 2010 viruses. Indeed, the USDAvalidated F-gene RRT-PCR assay failed to detect the 2010 isolates, whereas all viruses were detected by the cormorant F-gene RRT-PCR assay (18). These findings suggest that the 2010 isolates may have originated from the 2008 viruses or that the two outbreaks may have been caused by the same epizootic virus.
Although vNDV has been frequently associated with outbreaks of ND in cormorants, the epidemiology of NDV infection in this species is still not completely understood. It has been hypothesized that adult birds may play a critical role in maintaining NDV in cormorant populations (4). Adult and older juvenile birds, which are resistant to clinical ND, may carry NDV subclinically, thus spreading the virus to birds from distinct geographic areas during wintering (4). Birds subclinically infected in wintering grounds reinitiate the disease cycle in the nesting sites after spring migration (4). This dynamic cycle of NDV in cormorants may partially explain the eastward expansion of the virus during the 2010 outbreaks when compared to the 2008 outbreaks. It is possible that adult birds subclinically infected during the 2008 outbreaks in Minnesota have spread the virus, during wintering, to birds from eastern nesting sites, thereby leading to the 2010 outbreaks in Massachusetts, Maine, New Hampshire, and Maryland. However, a complete epidemiologic-surveillance study is needed to draw definitive conclusions about the source of the 2010 outbreaks.

In summary, the 2010 cormorant NDV isolates are closely related to the 2008 viruses, following the new evolutionary trend observed in cormorant NDV isolates since 2005. Although such evolutionary changes had no apparent effect on virus virulence, they are responsible for the failure of the USDA-validated F-gene RRT-PCR assay to detect the cormorant and gull viruses, making necessary the use of a cormorant-specific F-gene RRT-PCR assay (18) for the diagnosis of NDV in these species. Isolation of virulent NDV from multiple wild bird species (cormorants and gulls) and in close proximity with the Delmarva poultry industry in Maryland poses a significant threat to poultry species and highlights the need for constant epidemiologic surveillance for NDV in wild bird populations and for consistent biosecurity measures to prevent the introduction of the agent into commercial poultry flocks.

\section{REFERENCES}

1. Aldous, E. W., J. K. Mynn, J. Banks, and D. J. Alexander. A molecular epidemiological study of avian paramyxovirus type 1 (Newcastle disease virus) isolates by phylogenetic analysis of a partial nucleotide sequence of the fusion protein gene. Avian Pathol. 32:239-256. 2003.

2. Alexander, D. J. Newcastle disease and other avian paramyxoviruses. In: A laboratory manual for the isolation and identification of avian pathogens, 4th ed. D. E. Swayne, J. R. Glisson, M. W. Jackwood, J. E. Pearson, and W. M. Reed, eds. International Book Distributing Co., Tallahassee, FL. pp. 156-163. 2006.

3. Alexander, D. J., and D. A. Senne. Newcastle disease, other avian paramyxoviruses, and pneumovirus infections. In: Diseases of poultry, 12th ed. Y. M. Saif, A. M. Fadly, J. R. Glisson, L. R. McDougald, L. K. Nolan, and D. E. Swayne, eds. Blackwell Publishing, Ames, IA. pp. 75-98. 2008.

4. Allison, A. B., N. L. Gottdenker, and D. E. Stallknecht. Wintering of neurotropic velogenic Newcastle disease virus and West Nile virus in doublecrested cormorants (Phalacrocorax auritus) from the Florida Keys. Avian Dis. 49:292-297. 2005.

5. Blaxland, J. D. Newcastle disease in shags and cormorants and its significance as a factor in the spread of the disease among domestic poultry. Vet. Rec. 63:731-733. 1951.

6. Felsenstein, J. Confidence limits on phylogenesis: an approach using the bootstrap. Evolution 39:783-791. 1985.

7. Glaser, L. C., I. K. Barker, D. V. Weseloh, J. Ludwig, R. M. Windingstad, D. W. Key, and T. K. Bollinger. The 1992 epizootic of Newcastle disease in double-crested cormorants in North America. J. Wildl. Dis. 35:319-330. 1999.

8. Heckert, R. A. Ontario. Newcastle disease in cormorants. Can. Vet. J. 34:184. 1993.

9. Heckert, R. A., M. S. Collins, R. J. Manvell, I. Strong, J. E. Pearson, and D. J. Alexander. Comparison of Newcastle disease viruses isolated from 
cormorants in Canada and the USA in 1975, 1990 and 1992. Can. J. Vet. Res. 60:50-54. 1996.

10. Kuiken, T. Review of Newcastle disease in cormorants. J. Waterbirds Soc.; Waterbirds 22:333-347. 1999.

11. Kuiken, T., D. Frandsen, and A. Clavijo. Newcastle disease in cormorants. Can. Vet. J. 39:299. 1998.

12. Kuiken, T., F. A. Leighton, G. Wobeser, K. L. Danesik, J. Riva, and R. A. Heckert. An epidemic of Newcastle disease in double-crested cormorants from Saskatchewan. J. Wildl. Dis. 34:457-471. 1998.

13. Kuiken, T., G. Wobeser, F. A. Leighton, D. M. Haines, B. Chelack, J. Bogdan, L. Hassard, R. A. Heckert, and J. Riva. Pathology of Newcastle disease in double-crested cormorants from Saskatchewan, with comparison of diagnostic methods. J. Wildl. Dis. 35:8-23. 1999.

14. Lamb, R. A., and G. D. Parks. Paramyxoviridae: the viruses and their replication. In: Field's virology, 5th ed. D. M. Knipe, P. M. Howley, D. E. Griffin, R. A. Lamb, M. A. Martin, B. Roizman, and S. E. Straus, eds. Lippincott Williams \& Wilkins, Philadelphia. pp. 1449-1496. 2007.

15. McLachland, N. J., and E. J. Dubovi. Paramyxoviridae. In: Fenner's veterinary virology, 4th ed. N. J. McLachland, and E. J. Dubovi, eds. Academic Press, London. pp. 299-325. 2011

16. Miller, P. J., and C. L. Afonso. Newcastle disease virus. In: Encyclopedia of life sciences. John Wiley and Sons, Ltd., Chichester, U.K. pp. 1-9. 2011.

17. [OIE] World Organisation for Animal Health. Newcastle Disease. In Manual of diagnostic tests for terrestrial animals: mammals, birds and bees, 7th ed. OIE, Paris, France. pp. 576-589. 2009.

18. Rue, C. A., L. Susta, C. C. Brown, J. M. Pasick, S. R. Swafford, P. C. Wolf, M. L. Killian, J. C. Pedersen, P. J. Miller, and C. L. Afonso. Evolutionary changes affecting rapid identification of 2008 Newcastle disease viruses isolated from double-crested cormorants. J. Clin. Microbiol. 48:2440-2448. 2010
19. Saitou, N., and M. Nei. The neighbor-joining method: a new method for reconstructing phylogenetic trees. Mol. Biol. Evol. 4:406-425. 1987.

20. Samal, S. K. Paramyxoviruses of animals. In: Encyclopedia of virology, 3rd ed. Lippincott Williams and Wilkins, Philadelphia. pp. 40-47. 2008.

21. Seal, B. S. Analysis of matrix protein gene nucleotide sequence diversity among Newcastle disease virus isolates demonstrates that recent disease outbreaks are caused by viruses of psittacine origin. Virus Genes 11:217-224. 1995.

22. Sleeman, J. Summary of 2010 Newcastle disease virus outbreaks in wild birds in upper Midwest and the Northeast. Wildl. Health Bull. 2010:1-3. 2010.

23. Tamura, K., J. Dudley, M. Nei, and S. Kumar. MEGA4: Molecular evolutionary genetics analysis (MEGA) software version 4.0. Mol. Biol. Evol. 24:1596-1599. 2007.

24. Tamura, K., M. Nei, and S. Kumar. Prospects for inferring very large phylogenies by using the neighbor-joining method. Proc. Natl. Acad. Sci. U. S. A. 101:11030-11035. 2004.

25. Wise, M. G., D. L. Suarez, B. S. Seal, J. C. Pedersen, D. A. Senne, D. J. King, D. R. Kapczynski, and E. Spackman. Development of a real-time reverse-transcription PCR for detection of Newcastle disease virus RNA in clinical samples. J. Clin. Microbiol. 42:329-338. 2004.

26. Wobeser, G., F. A. Leighton, R. Norman, D. J. Myers, D. Onderka, M. J. Pybus, J. L. Neufeld, G. A. Fox, and D. J. Alexander. Newcastle disease in wild water birds in western Canada, 1990. Can. Vet. J. 34:353-359. 1993

\section{ACKNOWLEDGMENTS}

We thank Dawn Williams-Coplin and Tim Olivier for technical assistance and the SEPRL sequencing facility personnel for nucleotide sequencing. 